\title{
ASSESSMENT OF ADOPTION OF SOIL CONSERVATION PRACTICES AMONG ARABLE CROP FARMERS IN IMO STATE, NIGERIA
}

\author{
Okoroh, Juochi Patience ${ }^{1}$; Onuh Martins Onuh ${ }^{2}$; Ejike, D. Roseline ${ }^{1}$ \\ ${ }^{1}$ Department of Agricultural Economics, Extension and Rural Development, Imo State University, Owerri, Nigeria. \\ ${ }^{2}$ Department of Crop Science and Biotechnology, Imo State University, Owerri, Nigeria. \\ *Corresponding Author
}

DOI: https://doi.org/10.51193/IJAER.2021.7611

Received: 28 Nov. 2021 / Accepted: 06 Dec. 2021 / Published: 27 Dec. 2021

\begin{abstract}
Soil erosion severely threatens the soil resource and the sustainability of agriculture. After decades of research, this problem still persists, despite the fact that adequate technical solutions now exist for most situations. This begs the question as to why soil conservation is not more rapidly and generally implemented. Incidentally, empirical studies that documented the adoption of soil conservation practices among arable crop farmers in the area is still relatively scanty. These create emptiness in research and make it extremely difficult if not impossible for the government and stakeholders to know the method they can use in helping farmers mitigate the negative effect of soil erosion and poor soil nutrient in crops. It was against this backdrop that this study was systematically undertaken to assess the adoption of soil conservation practices among arable crop farmers in Imo state, Nigeria. The study specifically, described the socioeconomic characteristics of arable crop farmers in Imo State, ascertained soil conservation practices disseminated to crop farmers, assessed the awareness and adoption of soil conservation practices among arable crop farmers, assessed farmers' willingness to pay for soil conservation practices, assessed the economics of soil conservation practices among arable crop farmers, determined factors influencing the adoption of soil conservation practices and ascertained the constraints to adoption of soil conservation practices in the study area. The survey was conducted from March, 2020 through November 2021. Data were elicited from 405 arable crop farmers selected across Imo State, Nigeria. Data collected were analyzed using descriptive statistical tools such as means, flow-chart, percentage, likert scale-type and Cost-Benefit Analysis (CBA). Mean age was 41.00 years. Greater proportions (66.17\%) were female.
\end{abstract}


International Journal of Agriculture and Environmental Research

ISSN: 2455-6939

Volume: 07, Issue: 06 "November-December 2021"

Approximately $97.28 \%$ were aware of soil conservation measures while about $68.64 \%$ were not visited by extension agents. Average farm size was 1.36 ha. Result shows that mixed cropping $(98.98 \%)$ and planting of cover crops $(98.22 \%)$ were among the soil conservation practices disseminated to farmers in the area. About $76.05 \%$ had willingness to pay for soil conservation measures while income (96.79\%) and affordable soil conservation technologies $(92.59 \%)$ were among the reason for willingness to pay. Result further shows that farmers were already within the adoption Stage (AS) of mixed cropping ( $X=2.63$; $S D=0.81)$; and planting cover crops $(\bar{X}=2.68 ; \mathrm{SD}=0.91)$ amongst others. Net Present Value (NPV) revealed that intercropping and mixed cropping had greater return on investment with a value of $\$ 536,880$ and $\$ 479,995$ respectively in an average farming season. Result further shows that cost $(\bar{X}=3.55 ; \mathrm{SD}=0.76)$; Availability $(\bar{X}=3.44 ; S D=0.66)$ and Simplicity $(\bar{X}=3.67 ; S D=0.89)$ amongst others were some of the factors that positively encourages while complexity $(\bar{X}=1.74 ; S D=0.21)$ discourages adoption of soil conservation practices in the area. Soil conservation measures have been invaluable to farmers in the area. Regrettably, farmers complained of Inadequate adoption fund (96.54\%) and Limited availability of farmland (93.83\%).The study recommends that farmers should collectively pool productive resources together through cooperative society as these would enable them have access to financial resources, project a collective demand and benefit more from the practice of soil conservation measures. Also arable crop farmers should be encouraged to practice afforestation, as it will not only conserve the soil but also our climate.

Keywords: Adoption, Arable Crop Farmers, Soil Conservation practices, Imo State, Nigeria

\section{INTRODUCTION}

The problems posed by advent of the change in climate among farmers are serious problem today that requires the attention of all. Climate change is one of the most serious environmental threats facing mankind worldwide (Akinnagbe, Onah, Olaolu and Ajayi, 2014). This problem has a direct effect on agriculture in several ways, including its direct impact on food production (Enete and Amusa, 2010). The main human activity that is most likely to have a large impact on climate is the burning of "fossil fuel" such as coal, oil and gas and these fuels contained carbon. The impacts of climate change are more pronounced in sub Saharan Africa because agricultural productivity greatly depends on precipitation and natural conditions of the environment (Akinnagbe et al., 2014). This situation is actually further critical as the extent of the changes in climate are taking place in environments characterized by extreme poverty is high as there are limitations to what to give attention to among the populace. One key effect of climate change is increased rain fall which on the long run leads to erosion which has grave implications on agricultural practices. This is despite the fact that soil on its own is faced with great stress already owning to increased populations. Soil is the most important resource on which 
International Journal of Agriculture and Environmental Research

ISSN: 2455-6939

Volume: 07, Issue: 06 "November-December 2021"

sustainable agriculture and livelihood of the farmers is based, this makes the proper management of this valuable resource vital to uphold long-term agricultural productivity for farmers. Probably, no less than a quarter of the world population belongs to farm households and most of which are in less developed countries of the world (Ellis, 2000), Nigeria inclusive. Hence, the increased pressure on the available soil for food production most especially among developing nations of the world. FAO (2007) affirmed that the use of soil for agricultural production is one of the strongest influences affecting environmental quality in many developing countries. Specifically, practices like unguided application of agrochemicals, bush burning, deforestation, grazing, continuous tillage and uncontrolled farm mechanization affect the quality of soil and vegetation cover, thereby resulting into soil degradation. Soil degradation and desertification are already severe issues in Sub Saharan Africa, where smaller size and poor farmers follow extractive farming practices. Soil depletion and erosion thus constitute a hazard whose containment is a pre-requisite for national development, particularly in societies that are agriculture based like ours (Iheke and Onyenorah, 2012). Iheke et al (2012) noted that land degradation will remain an important global issue for the 21 st century because of its adverse impact on agronomic productivity, the environment, and its effect on food security and the quality of life. Land degradation can be considered in terms of the loss of actual or potential productivity or utility as a result of natural or anthropic factors; it is the decline in land quality or reduction in its productivity. Thus a need for the conservation of the soil to ensure sustainability of derived benefits and potentials of the soil. More, so rural farmers often aim at maximizing immediate returns from the land regardless of erosion. It has been noted that yields of crops are higher on crop farms with conservation practice than farms without conservation practices in the same ecological zone (Ibewiro et al., 2000; Salako and Tian, 2003; and Tian et al., 1999). However, Aromolaran (1998) stated that land owners receive the benefits of soil conservation in the long term. According to him, the maintenance of soil productivity in the long run is a proper social goal of conservation but it is only a minor- economic factor influencing the small- scale farmers. Soil erosion severely threatens the soil resource and the sustainability of agriculture. After decades of research, this problem still persists, despite the fact that adequate technical solutions now exist for most situations. This begs the question as to why soil conservation is not more rapidly and more generally implemented. Studies show that the implementation of soil conservation measures depends on a multitude of factors but it is also clear that rapid change in agricultural systems only happens when a clear economic incentive is present for the farmer. Conservation measures are often more or less cost-neutral, which explains why they are often less generally adopted than expected. It was against this background that this study assessed the adoption of soil conservation practices among farmers in the course of their farming activities.

\section{METHODOLOGY}


The study was carried out in Imo State, Nigeria. Imo State is located in the eastern zone of Nigeria. The State lies between Latitudes $4^{\circ} 45^{\prime} \mathrm{N}$ and $7^{\circ} 15^{\prime} \mathrm{N}$ and Longitude $6^{\circ} 50^{\prime} \mathrm{E}$ and $7^{\circ} 25^{\prime} \mathrm{E}$ (Nigerian Meteorological Agency (NiMET), 2016). It is bounded on the east by Abia State, on the west by the River Niger and Delta State; and on the north by Anambra State, while Rivers State lies to the south (National Boundary Commission (NBC), 2020). Imo State covers an area of about 5,067.20 $\mathrm{km}^{2}$, with a population of 3,934,899 [(National Population Commission (NPC), 2006; National Bureau of Statistics (NBS), 2007)] and population density of about 725 $\mathrm{km}^{2}$ (Ministry of Land Survey and Urban Planning, 2015). The State has three Agricultural zones namely Okigwe, Orlu and Owerri Agricultural Zones. Structured questionnaire was used for data collection.

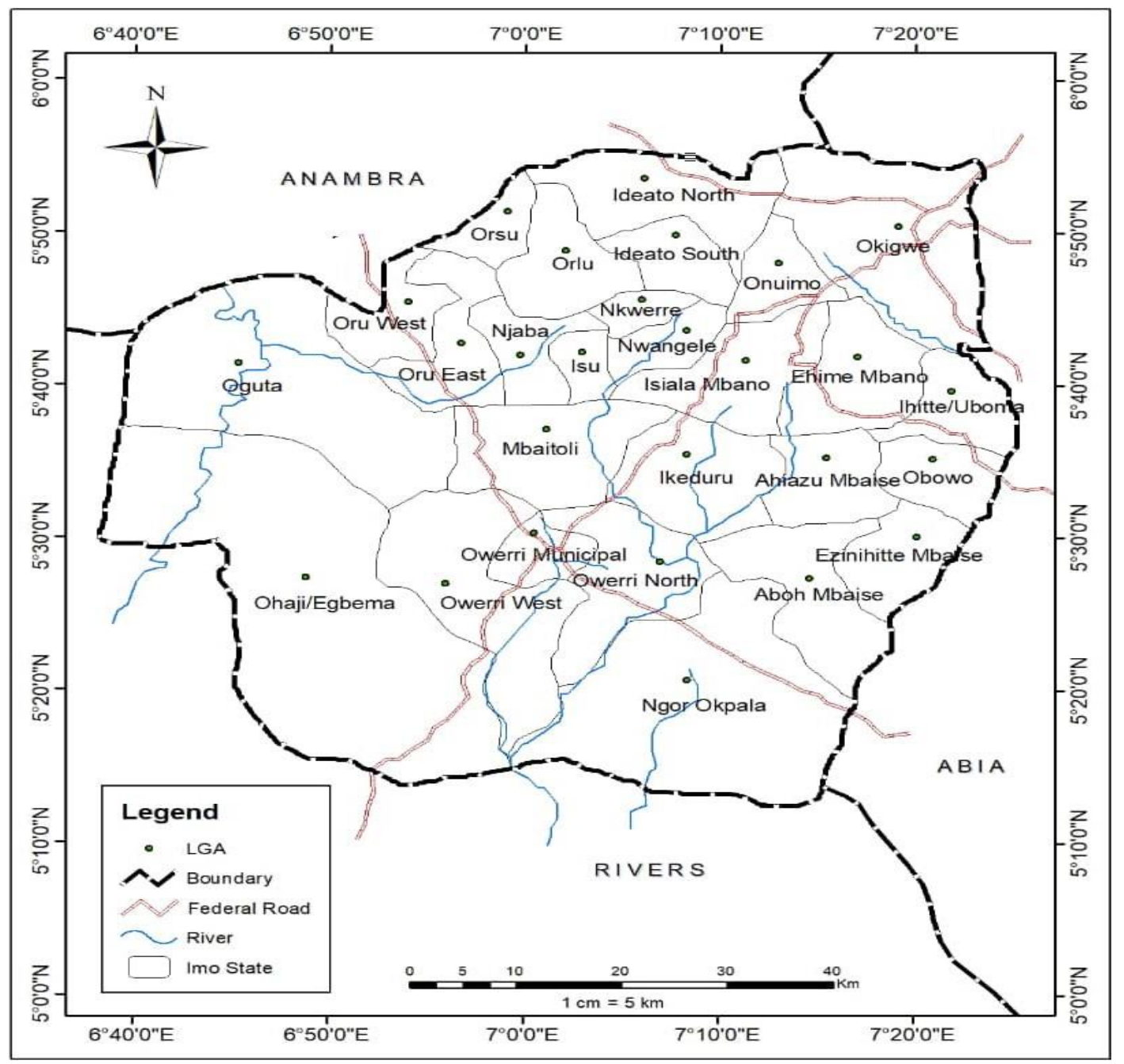

Figure 1: Map of Imo State Showing the 27 LGAs; Researchers GIS Mapping (2021) 
International Journal of Agriculture and Environmental Research

ISSN: 2455-6939

Volume: 07, Issue: 06 "November-December 2021"

The questionnaire was subjected to content and face validity through the help of experts. The population of the study consisted of all farmers currently involved in arable crop farming within Imo State. A multi Stage-sampling was used to select three agricultural zones in the state. The three agricultural zones in Imo were sampled. From each sampled zone, three (3) Agricultural blocks was purposively selected based on the intensity of arable crop production and Imo State Agricultural development Programme delineations. This gave a total of six (6) blocks sampled in all. From each block sampled, three (3) cells were sampled from each block which gave a total of 27 cells sampled. From each cell, 15 practicing arable crop farmers were sampled which gave a total of 405 arable crop farmers for the study. Data collected were analyzed using descriptive statistical tools such as means, flow-chart, percentage, likert scale-type and Cost-Benefit Analysis (CBA). Specifically, a4-point Likert scale type rating of Strongly Agreed (SA) (4); Agreed (A) (3), Disagreed (D) (2); and Strongly Disagreed (SD) (1) was used in achieving the factors affecting the adoption of soil conservation practices in the area and then divided by the number of scales to obtain the discriminating index e.g $(4+3+2+1) / 4=2.50$ cut-off point. Also, 4-point Likert scale type rating of Aware (A) (1); Interest (I) (2); Evaluation (E) (3); Trail (I) (4); Adoption (A) (6) and Satisfaction (7) (1) achieving the adoption of soil conservation measures among arable crop farmer in the area and then divided by the number of scales to obtain the discriminating index e.g $(1+2+3+4+5+6+7) / 7=4.00$ cut-off point.

Decision rule;

Less than $0.10=$ Aware stage of soil conservation measures

1.00-1.49 = Interest stage of soil conservation measures

1.50-1.99 = Evaluation stage of soil conservation measures

2.00-2.49 $=$ Trail stage of soil conservation measures

2.50-2.99 $=$ Adoption stage of soil conservation measures

3.00-3.49 = Satisfaction stage of soil conservation measures

Equally, the formula for the Cost-Benefit Analysis (CBA) was given as Net Present Value (NPV) $=\sum$ Present Value of Future Benefits $-\sum$ Present Value of Future Costs. Then formula for benefit cost ratio was stated as Benefit-Cost Ratio $=\sum$ Present Value of Future Benefits / $\sum$ Present Value of Future Costs. 


\section{RESULTS AND DISCUSSION}

\subsection{Socio-economic Characteristics of Arable Crop Farmers}

Table 1 revealed that majority $(55.80 \%)$ fell within the age range of $41-50$ years. The mean age was 41.00 years. This shows that farmers in the area are vibrant, young and still within the active age. Arable crop farming is so strenuous. The implication is that younger farmers are more likely to adopt and practice more and modern social conservation measures method faster than the older ones. Young farmers are more likely to know about new strategies to avert soil erosion to increase crop yield and with the willingness to bear risk than their older counterpart. The result is in agreement with the study of Aja, Ani, Matthews-Njoku and Ifeanyi-Obi (2015) who reported that younger farmers normally dominate such strenuous ventures such as farming than older farmers in South-east Nigeria and that older farmers are not always enthusiastic about new indigenous knowledge technologies, especially if the benefits are not foreseeable over time. Table 1 also reveals that majority (66.17\%) of the farmers were females. The finding implies that both sex are involved in arable crop farming but female are more in number in the area. Women make essential contributions to the agricultural and rural economies in all developing countries (FAO, 2020). Their roles vary considerably between and within regions and are changing rapidly in many parts of the world, where economic and social forces are transforming the agricultural sector just like in the study area,

TABLE 1: Socio-economic Characteristics of Arable Crop Farmers

\begin{tabular}{|l|l|l|l|}
\hline Age (years) & Frequency & Percentage (\%) & Mean (X) \\
\hline $21-30$ & 8 & 1.98 & \\
\hline $31-40$ & 49 & 12.10 & \\
\hline $41-50$ & 226 & 55.80 & 41.00 years \\
\hline $51-60$ & 78 & 19.26 & \\
\hline $61-70$ & 32 & 7.90 & \\
\hline $71-80$ & 12 & 2.96 & \\
\hline Total & $\mathbf{4 0 5}$ & $\mathbf{1 0 0 . 0}$ & \\
\hline Sex & Frequency & Percentage (\%) & \\
\hline Female & 268 & 66.17 & \\
\hline Male & 137 & 33.83 & \\
\hline Total & $\mathbf{4 0 5}$ & $\mathbf{1 0 0 . 0}$ & \\
\hline Educational Level & Frequency & Percentage (\%) & \\
\hline No formal education & 9 & 2.22 & \\
\hline Primary & 133 & 32.84 & \\
\hline Secondary & 246 & 60.74 & \\
\hline Tertiary & 17 & 4.20 & \\
\hline Total & $\mathbf{4 0 5}$ & $\mathbf{1 0 0 . 0 0}$ & \\
\hline
\end{tabular}

www.ijaer.in 
International Journal of Agriculture and Environmental Research

ISSN: 2455-6939

Volume: 07, Issue: 06 "November-December 2021"

\begin{tabular}{|c|c|c|c|}
\hline Marital Status & Frequency & Percentage (\%) & \\
\hline Married & 211 & 52.10 & \\
\hline Single & 135 & 33.33 & \\
\hline Widowed & 47 & 11.60 & \\
\hline Divorced & 12 & 2.96 & \\
\hline Total & 405 & 100.0 & \\
\hline Farming Experience (Years) & Frequency & Percentage (\%) & \\
\hline $01-10$ & 10 & 2.47 & \\
\hline $10-19$ & 24 & 5.93 & \\
\hline $20-30$ & 233 & 57.53 & 21 years \\
\hline $31-40$ & 86 & 21.23 & \\
\hline $41-50$ & 41 & 10.12 & \\
\hline $51-60$ & 11 & 2.72 & \\
\hline Total & 405 & 100.00 & \\
\hline $\begin{array}{l}\text { Household Size (Number of } \\
\text { Persons) }\end{array}$ & Frequency & Percentage (\%) & \\
\hline $1-2$ & 3 & 0.74 & \\
\hline $3-4$ & 13 & 3.22 & \\
\hline $5-6$ & 23 & 5.68 & \\
\hline $7-8$ & 217 & 53.58 & 8 persons \\
\hline $9-10$ & 67 & 16.54 & \\
\hline $11-12$ & 77 & 19.01 & \\
\hline $13-14$ & 5 & 1.23 & \\
\hline Total & 405 & 100.00 & \\
\hline Extension Contact & Frequency & Percentage (\%) & \\
\hline Not at all & 278 & 68.64 & \\
\hline Once in a fortnight & 89 & 21.98 & \\
\hline Once in a month & 28 & 6.91 & \\
\hline Once in a year & 10 & 2.47 & \\
\hline Total & 405 & 100.00 & \\
\hline Access to Credit & Frequency & Percentage (\%) & \\
\hline Access & 307 & 75.80 & \\
\hline No-access & 98 & 24.20 & \\
\hline Total & 405 & 100.00 & \\
\hline Farm Size (Ha) & Frequency & Percentage (\%) & \\
\hline $0.1-1.0$ & 101 & 24.94 & \\
\hline $1.1-2.0$ & 244 & 60.25 & 1.36ha \\
\hline $2.1-3.0$ & 43 & 10.62 & \\
\hline $3.1-4.0$ & 17 & 4.20 & \\
\hline
\end{tabular}


International Journal of Agriculture and Environmental Research

ISSN: 2455-6939

Volume: 07, Issue: 06 "November-December 2021"

\begin{tabular}{|l|l|l|l|}
\hline Total & $\mathbf{4 0 5}$ & $\mathbf{1 0 0 . 0}$ & \\
\hline Monthly Farm Income ( $)$ & Frequency & Percentage (\%) & \\
\hline $10,000-20,000$ & 2 & 0.49 & \\
\hline $20,001-30,000$ & 39 & 9.63 & \\
\hline $30,001-40,000$ & 50 & 12.35 & \\
\hline $40,001-50,000$ & 32 & 7.90 & \\
\hline $60,001-70,000$ & 203 & 50.12 & \#60,100.00 (1,466.28USD) \\
\hline $70,001-80,000$ & 44 & 10.86 & \\
\hline $80,001-90,000$ & 23 & 5.68 & \\
\hline $90,001-100,000$ & 12 & 2.96 & \\
\hline Total & $\mathbf{4 0 5}$ & $\mathbf{1 0 0 . 0 0}$ & \\
\hline & & & \\
\hline
\end{tabular}

Source: Field Survey Data, 2021

Entries in Table 1 also show that greater proportion $(60.74 \%)$ had secondary school education. The finding implies that approximately $97.78 \%$ of the farmers had formal education which is expected to increase their level of understanding and decision making on adoption and use of soil conservation practices in the area. The study also shares view with the finding of Wordofa, Okoyo and Erkalo (2020) who asserted that improved level of education brings about positive changes in knowledge, attitude and skills through research and extension services of the farmers. Result in Table 1 shows that majority $(52.10 \%)$ were married. The finding implies that arable crop farming is an enterprise of married individual who are expected to be responsible according to societal standard [8]. This finding supports the study of Daudu (2016) who found that married farmers tend to have more access to farm resources such as land and large family size to compliment farm labour. The implication of the finding is that farmers would adopt better and several soil conservation measures as they have access to large family size which are most available to married people. Married farmers have likelihood of adopting soil conservation practices easily than their unmarried counterpart since they have access to labour. Result of farming experience is shown in Table 1 and it shows that about $57.53 \%$ of the farmers had a farming experience ranging from 20-30 years. The mean year of experience in farming was 21.00 years. This shows that the farmers were quite experienced in arable crop farming and have started been adopting and practicing several soil conservation practices to increase their farm yield and income in the area. It is expected that farmers with more experience are more likely to accept innovations on soil conservation practices to increase their farm yield and income than farmers with low years of farming experience. The finding is strengthened by the study of Oladipo, Bolarin, Daudu, Kayode and Awoyele (2017) who reported that experience in arable crop farming and soil conservation measures enhances decision making, better knowledge of use of the most appropriate control measures methods to improve crop yield, income and farmers standard of living. Outcome in Table 1 also show that majority (68.64\%) of the farmers had no 
International Journal of Agriculture and Environmental Research

ISSN: 2455-6939

Volume: 07, Issue: 06 "November-December 2021"

contact with extension agents. The implication is that majority of the farmers may not have the opportunity of learning new soil conservation measure and consequently exposing their farming to incidence soil erosion and low output becomes pertinent in the area. It becomes clear that there is need for the government to strengthen the Agricultural Development programme (ADP) in Imo State with modern ICTs gadgets and skills for personnel to facilitate timely extension contacts with farmers in the area. The result is in consonant with the study of Sahya, Oliver, Bornwell, Joseph, and Enock (2021) who asserted that effective agricultural extension is perceived to be one of the most important keys in advancing innovation and development to farmers. About $75.80 \%$ had access to farm credit. Access to farm credit avail farmers opportunity to access fund to adopt various soil conservation practices disseminated in the area. Entries in Table 1 revealed that about 53.58\% had a household size ranging from 7-8. The mean household size was found to be 8.00 persons. The result shows that farmers had large households. The implication is that farmers could draw farm labour from their households in their adoption and practice of soil conservation measure to increase their farm yield and income in the area. This finding support the result of Elenwa and Emodi (2019) who reported that large household size is a proxy to labour availability, ensure ease allocation of resources and reduce the cost of hired labour. Table 1 revealed that majority (60.25\%) of the farmers had farm size of between 1.10-2.00 hectares. The average farm size is 1.36ha. The finding implies that the farmers in the area are mainly smallholder farmers operating on less than or equal to 1.50 hectares of farmland. This could be as a result of land tenure system or increasing population prevalent in the area. Additionally, the small farm size is not even contiguous plot but rather small plots scattered in different areas of the community. It is expected that farmers with large farm size will adopt and practice more and better soil conservation practices than their counterpart with lesser farmland in the area. The finding is in line with the study Ademola and Olujide (2014) which found that of large farm size encourages adoption of several soil conservation practices by farmers to increase farm yield and income. Finally, Table 1 indicates that majority (50.12\%) had an average monthly farm income was between $\$ 60,001-\$ 70,000$. The mean annual farm income was $\$ 60,100.00$ (1,466.28USD) while yearly farm income was estimated to be 721,200 (1,759.54USD). The finding implies that the farmers have a relatively low farm income despite the larger household size which they recorded. The implication of the findings is that farmers may have several soil conservation practices to adopt, but inadequate fund will continue to pose a negative barrier. The study of Mohamed and Nageye (2021) found out that farmers with higher farm income will make better decision, use necessary productive inputs efficiently to realize huge yield/output as well as other farm objectives than their counterparts who have low farm income.

\subsection{Crop Farmers' Awareness of Soil Conservation Practices}


Result of the crop farmers distribution based on awareness of soil conservation practices is displayed in Figure1. It shows that larger proportion (97.28\%) of farmers were aware of soil conservation practices in the area. Therefore the finding implies that most of the arable crop farmers were aware of soil conservation practices and may have been adopting and applying several soil conservation measures in their farming activities over time in the area. The high awareness could be attributed to the fact that soil conservation practices over time may have been in close alignment with the culture and tradition which the farmers were already familiar with. In the same way, even though, awareness does not really signify adopting and practice, however, it could serve as an essential determinant to positively initiate adoption. The finding is in line with the study of Ojo, Egbelehulu, Olaleye, Ojo, Tsado and Ajayi (2013) who reported that awareness on soil conservation practices is vital in increasing adopting among arable crop farmers. Ultimately, the number of crop farmers (394) who were aware of soil conservation practices as found in this present objective were therefore used to analyze the subsequent objectives of the study.

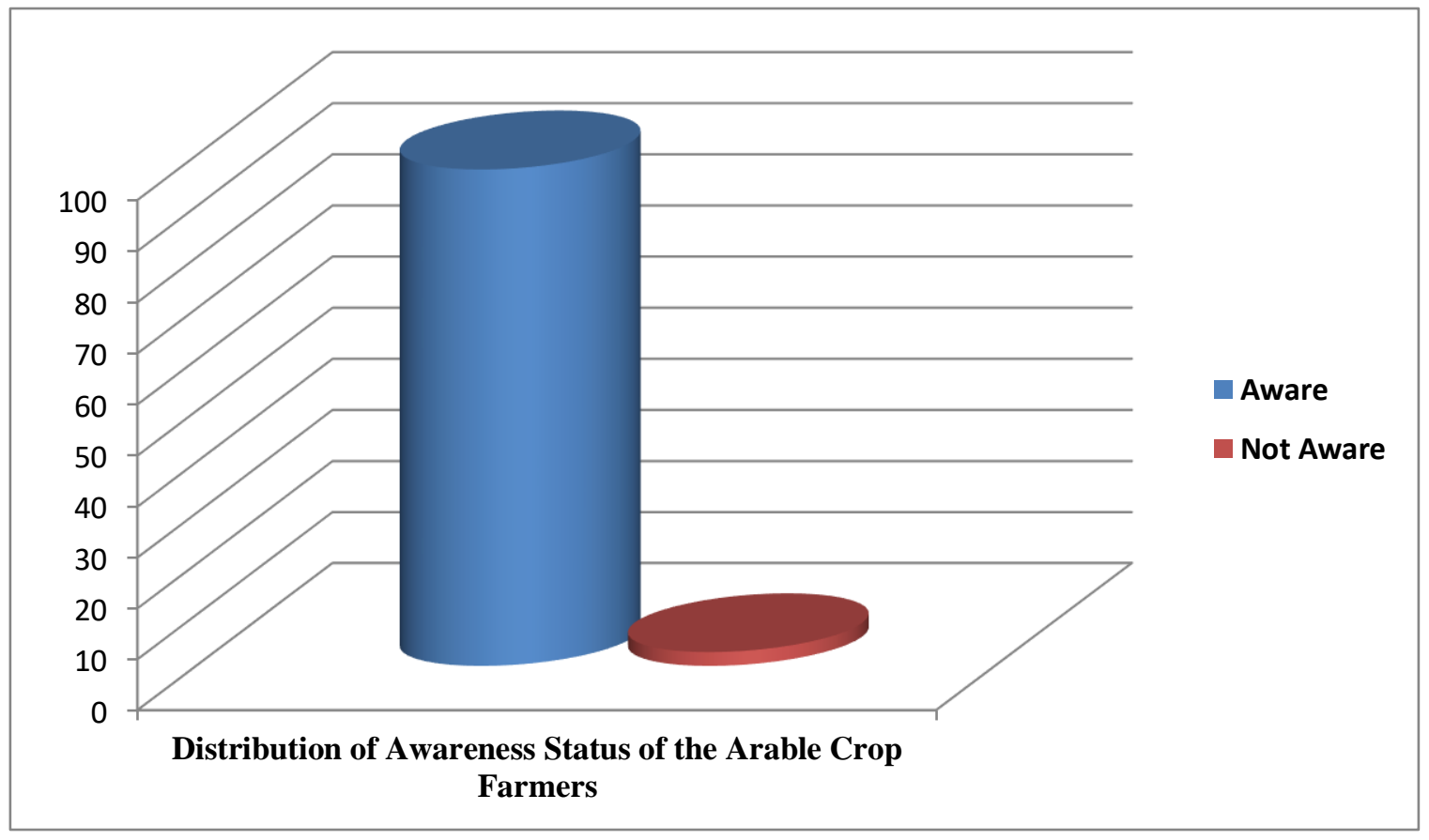

Figure 1, Source: Field Survey Data, 2021

\subsection{Soil Conservation Practices Disseminated to Arable Crop Farmers in the area}

Outcome of the soil conservation practices disseminated to arable crop farmers in the area is shownin Table 2. Result shows that mixed cropping (98.98\%), planting of cover crops (98.22\%), 
mulching (97.72\%) and application of organic fertilizer (96.45\%) among others were among the soil conservation practices disseminated by various agricultural agencies in the area. More, so, finding also shows application of inorganic fertilizer $(30.71 \%)$, contour bunds $(24.87 \%)$,creation of water channels $(8.12 \%)$ and soak-away pits $(3.55 \%)$ had a relatively low percentage of soil conservation practices disseminated in the area this could be attributed to the high cost of establishing these practices. Since, arable farmers are poor and lacking financial and material resources, it is unlikely that these technologies would be easily accepted and adopted in the area. The finding shows that there are many soil conservation measure Disseminated in the area. The result shared view with the study of Ndulue, Ayadiuno, Mozie and Ndichie (2021) who reported that soil conservation practices is gaining popularity due to demand for increasing farm yield and income of farmers always affected by menace of soil erosion and insufficient of soil nutrients.

Table 2: Soil Conservation Practices Disseminated to Crop Farmers in the area

\begin{tabular}{llll}
\hline S/No & Items & Frequency & Percentage (\%) \\
\hline 1 & Mixed cropping & 390 & 98.98 \\
2 & Planting of cover crops & 387 & 98.22 \\
3 & Mulching & 385 & 97.72 \\
4 & Application of organic fertilizer & 380 & 96.45 \\
5 & Contour planting & 373 & 94.67 \\
6 & Improved farrows & 370 & 93.91 \\
7 & Terracing & 374 & 94.92 \\
8 & Intercropping & 372 & 94.42 \\
9 & Zero tillage & 368 & 93.40 \\
10 & Crop rotation & 361 & 91.62 \\
11 & Afforestation & 355 & 90.10 \\
12 & Bush fallowing & 352 & 89.34 \\
13 & Salinity management & 234 & 59.40 \\
14 & Application of inorganic fertilizer & 121 & 30.71 \\
15 & Contour bunds & 98 & 24.87 \\
16 & Creation of water channels & 32 & 8.12 \\
$\mathbf{1 7}$ & Soak-away pits & 14 & 3.55 \\
\hline
\end{tabular}

*Multiple responses were recorded; Source: Field Survey Data, 2021

\subsection{Farmers' Willingness to Pay for Soil Conservation Practices}

Entries in Table 3 show farmers' willingness to pay for soil conservation practices in the area. It reveals that greater proportion $(76.05 \%)$ of the farmers were willing to pay for soil conservation practices. These could be attributed to an increasing need for farm yield and income that has pushed most farmers into having willingness to pay for soil conservation practices. the finding also shows that farmers will be more willing to pay for soil conservation practices if there is 
increase in income (96.79\%), affordable soil conservation technologies (92.59\%), local nature (adaptability) of the soil conservation measure (85.68\%) among others. The result is in line with the study Abu, Taangahar and Ekpebu (2011) who found that farmers are willing to pay for soil conservation practices if it meets their specific need, its affordable and there is availability of income.

Table 3: Farmers' Willingness to Pay for Soil Conservation Practices

\begin{tabular}{llll}
\hline S/No & Item & Frequency & Percentage (\%) \\
\hline 1 & Willing & 308 & 76.05 \\
2 & Unwilling & 97 & 23.95 \\
3 & Reasons for Willingness to Pay & Frequency & Percentage (\%) \\
1 & Income & 392 & 96.79 \\
2 & Affordable soil conservation technologies & 375 & 92.59 \\
3 & Local nature (adaptability) of the soil conservation measure & 347 & 85.68 \\
4 & Effectiveness of the soil conservation measure & 340 & 83.95 \\
6 & Availability of Local Material for the soil conservation & 333 \\
& measure & & 82.22 \\
7 & Time of result for the soil conservation measures (increase & \\
& yield easily) & 330 & 81.48 \\
8 & Access to input supplies of the soil conservation measures & 321 & \\
9 & Access to extension agents and research institute developing & 316 & 79.26 \\
& the soil conservation technologies & & 78.02 \\
10 & Relative advantage & 310 & 76.54 \\
11 & Availability & 289 & 71.36 \\
12 & Conserve moisture & 280 & 69.14 \\
13 & Less labour intensive & 275 & 67.90 \\
14 & Does not pollute the environment & 261 & 64.44 \\
15 & Increase soil biological activities & 256 & 63.21 \\
16 & Controls erosion & 250 & 61.73 \\
17 & Reduce effects of heat & 244 & 60.25 \\
18 & Suppress weeds & 232 & 57.28 \\
19 & Cheap in producing & 211 & 52.10 \\
\hline
\end{tabular}

*Multiple responses were recorded; Source: Field Survey Data, 2021

\subsection{Economics of soil conservation practices among crop farmers in Imo State}

Output in Table 4, shows the economics of soil conservation practices among crop farmers in Imo State, Nigeria. The results were molded using Cost-Benefit Analysis (CBA). The Net Present Value (NPV) was computed based on each of the soil conservation measures used and the return on investment for the arable crop farmers returns. The result shows that the soil conservation practices with the highest Net Present Value (NPV) were intercropping and mixed 
cropping with a value of $\$ 80,532$ and $\$ 71,999.25$ respectively on average. The use of both intercropping and mixed cropping could be attributed to both being one of the oldest form of systemized agricultural production. The study of asserted that Lizarazo, Tuulos, Jokela and Mäkelä (2020) both mixed and inter cropping reduces the risk of crop failure due to environmental stress., Pest infestation of crops and promotes good soil fertility, yield per hectare, and income of both the crops due to complementary effect of each crop. Hence, mixed and inter cropping may therefore become the most essential soil conservation measures in increasing yield and income in the face of soil degradation and loss of soil nutrient.Base on the above result it could be adjudged that the soil conservation measures practices by arable crop farmers in the study area are profitable given the outcome of the NPV. There is no doubt that if more investments are made on all the soil conservation measures yielding positive NPV, it will lead to a significant increase in income, yield, food security and standard of living on the farmers in the area and perhaps beyond.

Table 4: Economics of Soil Conservation Practices among Crop Farmers in Imo State

\begin{tabular}{|c|c|c|c|c|}
\hline Items & Cost (A) & Benefits (N) & Net Benefits ( & $\begin{array}{l}\text { NPV@15\% } \\
\text { Discount Rate (N) }\end{array}$ \\
\hline Mixed cropping & 50,849 & 530,844 & 479,995 & $71,999.25$ \\
\hline Planting of cover crops & 21,272 & 250,392 & 229,120 & 34,368 \\
\hline Mulching & 5,902 & 15,749 & 9,847 & $1,477.05$ \\
\hline Application of organic fertilizer & 16,859 & 62,862 & 46,003 & $6,900.45$ \\
\hline Contour planting & 10,746 & 53,756 & 43,010 & $6,451.5$ \\
\hline Improved farrows & - & -- & - & - \\
\hline Terracing & 36,950 & 80,840 & 43,890 & $6,583.5$ \\
\hline Intercropping & 203,840 & 740,720 & 536,880 & 80,532 \\
\hline Zero tillage & $\ldots$ & - & $\ldots$ & - \\
\hline Crop rotation & - & -- & -- & -- \\
\hline Afforestation & 79,039 & 200,852 & 121,813 & $18,271.95$ \\
\hline Bush fallowing & - & - & -- & -- \\
\hline Salinity management & 16,793 & 58,201 & 41,408 & $6,211.2$ \\
\hline $\begin{array}{l}\text { Application of inorganic } \\
\text { fertilizer }\end{array}$ & 52,084 & 100,850 & 48,766 & $7,314.9$ \\
\hline Contour bunds & 14,802 & 51,341 & 36,539 & $5,480.85$ \\
\hline Creation of water channels & 121,630 & 542,850 & 421,220 & 63,183 \\
\hline Soak-away pits & 273,985 & 240,720 & 33,265 & 5,532 \\
\hline
\end{tabular}

*Multiple responses were recorded; Source: Field Survey Data, 2021; Discount Rate $=15 \%$

\subsection{Factors affecting the adoption of soil conservation practices in Imo State, Nigeria}

Findings of arable crop farmers distribution based on factors affecting the adoption of soil conservation practices in Imo State, Nigeria is shown in Table 5. The various attributes were rated in a 4- point, Likert-type scale rating of Strongly Agreed (4); Agreed (3); Disagreed (2) and Strongly Disagreed (1). The finding indicates that farmers were in agreement with most of the items of organic farming practices in alleviating poverty in the area. The SD value which ranged 
from 0.50-1.00 indicates that the farmers were in agreement in their opinions regarding factors affecting the adoption of soil conservation practices in the area. From the result, most of the items that were rated high and with an acceptable overall discriminatory score $(\bar{x}=2.50)$ and Standard deviation (SD) includes; cost ( $\overline{\mathrm{x}}=3.55 ; \mathrm{SD}=0.76$ ); availability ( $\overline{\mathrm{x}}=3.44 ; \mathrm{SD}=0.66)$ and simplicity ( $\overline{\mathrm{x}}=3.67 ; \mathrm{SD}=0.89)$ amongst others. This is an indication that these acceptable items positively affected the adoption of soil conservation measures among arable crop farmers in the area. The result is in line with the initials study of Rogers (1995) and more recent study of Ikuerowo and Tehinloju (2020); explained that relative advantage, compatibility, complexity, trialability, and observability significantly affect the adoption of any given agricultural innovation. Finding also shows that complexity ( $\bar{x}=1.74 ; \mathrm{SD}=0.21$ ) of soil conservation measures affects their adoption negatively. Complexity is the degree to which an innovation is perceived as difficult to understand and use. The result tallies with the study of Solomon, Tadesse, Markew, and Wudineh (2021) who found that farmers area unable to accept and adopt technologies that are difficult to understand. Finally, the findings from the aggregate mean $(\overline{\mathrm{x}}=3.38 ; \mathrm{SD}=0.69)$ indicates that the farmers had a relatively higher level of adoption and acceptable of soil conservation measures in the area. The relatively high level of adoption could be as a result of positive factors and relative advantage associated with the adoption of each soil conservation technologies found in the study. 
International Journal of Agriculture and Environmental Research

ISSN: 2455-6939

Volume: 07, Issue: 06 "November-December 2021"

Table 5: Factors affecting the adoption of soil conservation practices in Imo State, Nigeria

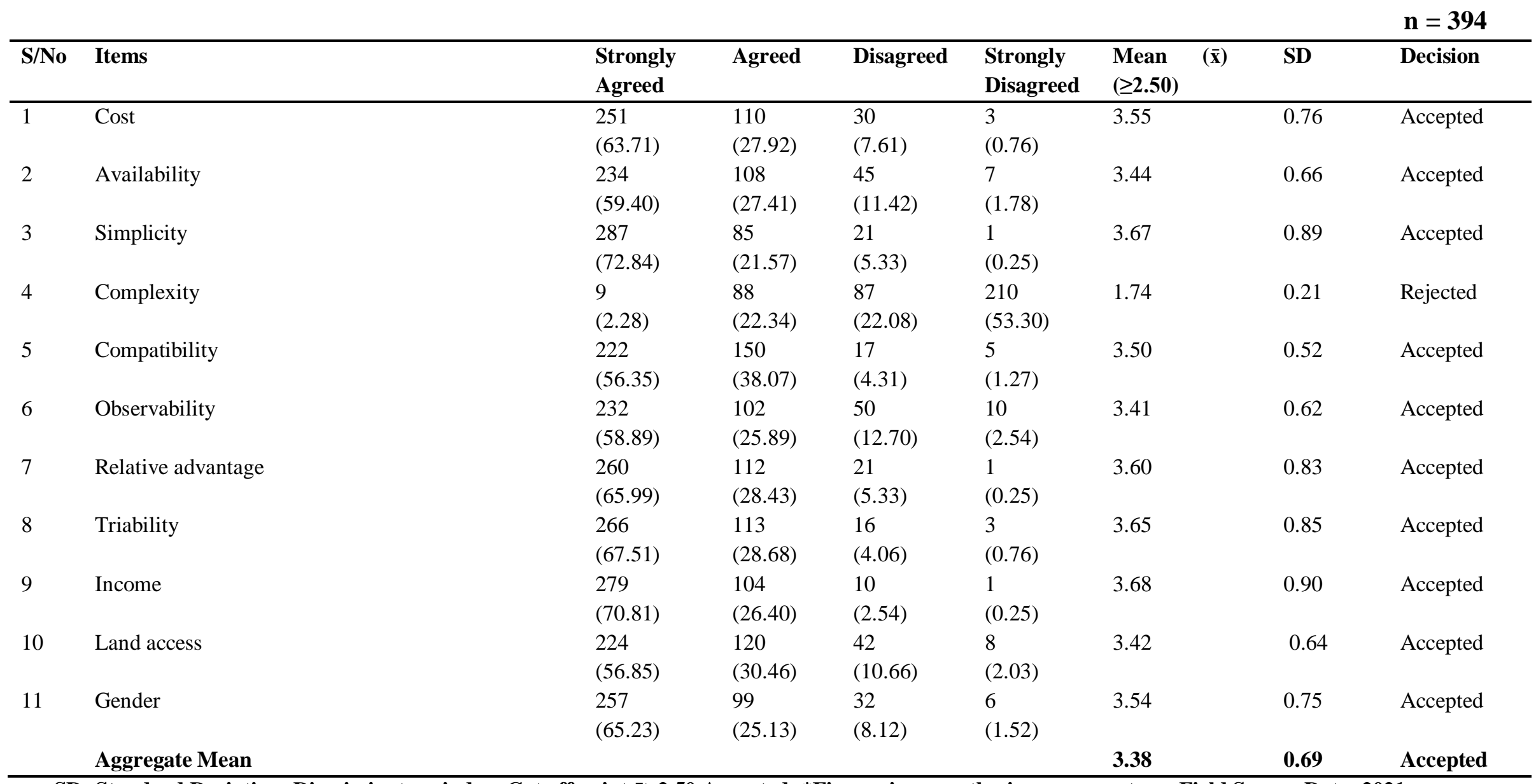

SD; Standard Deviation; Discriminatory index: Cut off point $\bar{x} \geq 2.50$ Accepted; *Figures in parenthesis are percentage; Field Survey Data, 2021 
International Journal of Agriculture and Environmental Research

ISSN: 2455-6939

Volume: 07, Issue: 06 "November-December 2021"

\subsection{Adoption of Soil Conservation Practices among Arable farmers}

Result of arable crop farmers distribution on Adoption of Soil Conservation Practices among Arable farmers is shown in Table 6. The various attributes were rated in a 6- point Likert type rating scale questions of Aware (A) (1); Interest (I) (2); Evaluation (E) (3); Trail (I) (4); Adoption (A) (6) and Satisfaction (7) (1). The result were also rated with various adoption level decision rule of less than 1.00 for aware stage of soil conservation practices; $1.00-1.49$ for Interest stage; 1.50-1.99 for Evaluation stage; 2.00-2.49 for Trail stage; 2.50-2.99 for Trail stage; 3.00- 3.49 for Adoption stage and finally 3.50 and above for satisfaction stage. The Standard deviation (SD) value which ranged from 0.50-1.00 indicated that the farmers were in agreement in their opinions regarding their various stages of adoption of various conservation practices; disseminated in the area. From all the items measure, result shows that farmers were more within the Adoption stage (AS) of Mixed cropping ( $\bar{x}=2.63$; $S D=0.81$ ),Planting of cover crops $(\bar{x}=2.68$; $\mathrm{SD}=0.91)$, Mulching $(\overline{\mathrm{x}}=2.63 ; \mathrm{SD}=0.87)$ amongst others, except with Application of inorganic fertilizer $(\bar{x}=0.29 ; \mathrm{SD}=0.21)$, Creation of water channels $(\overline{\mathrm{x}}=0.38 ; \mathrm{SD}=0.29)$, soak-away pit $(\overline{\mathrm{x}}=0.37 ; \mathrm{SD}=0.26)$ and Afforestation $(\overline{\mathrm{x}}=0.46 ; \mathrm{SD}=0.23)$ which were found to fall within the Interest Stage (IS) of the farmers. This also significantly justifies the relative effort extension agents are making in increasing awareness of farmers on soil conservation practices. It is likely that the cost of establishment of these soil conservation practices is the reasons why famers are still within the awareness stage. The result is in line with the study of Ojo et al. (2013) who found that adoptions of soil conversation measures are costly and farmers with limited farm income are unlikely to adopt and practice. The findings from the aggregate mean $(\bar{x}=2.51$; $\mathrm{SD}=0.66$ ) indicates that the farmers accepted their various stages of adoption of soil conservation practices in the area. 
Volume: 07, Issue: 06 "November-December 2021"

Table 6: Adoption of Soil Conservation Practices among Arable farmers

\begin{tabular}{|c|c|c|c|c|c|c|c|c|c|c|}
\hline S/No & Items & $\mathbf{A}$ & I & $\mathbf{E}$ & $T$ & Ap & $\mathbf{S}$ & Mean $(\overline{\mathbf{x}})$ & SD & Decision \\
\hline 1 & Mixed cropping & $\begin{array}{l}2 \\
(0.51)\end{array}$ & $\begin{array}{l}9 \\
(2.28)\end{array}$ & $\begin{array}{l}11 \\
(2.80)\end{array}$ & $\begin{array}{l}19 \\
(4.82)\end{array}$ & $\begin{array}{l}180 \\
(45.69)\end{array}$ & $\begin{array}{l}173 \\
(43.91)\end{array}$ & 2.63 & 0.81 & Adoption Stage \\
\hline 2 & Planting of cover crops & $\begin{array}{l}5 \\
(1.27)\end{array}$ & $\begin{array}{l}15 \\
(3.80)\end{array}$ & $\begin{array}{l}24 \\
(6.09)\end{array}$ & $\begin{array}{l}44 \\
(11.17)\end{array}$ & $\begin{array}{l}156 \\
(39.60)\end{array}$ & $\begin{array}{l}150 \\
(38.07)\end{array}$ & 2.68 & 0.91 & Adoption Stage \\
\hline 3 & Mulching & $\begin{array}{l}3 \\
(0.76)\end{array}$ & $\begin{array}{l}5 \\
(1.27)\end{array}$ & $\begin{array}{l}18 \\
(4.57)\end{array}$ & $\begin{array}{l}26 \\
(6.60)\end{array}$ & $\begin{array}{l}169 \\
(42.90)\end{array}$ & $\begin{array}{l}173 \\
(43.91)\end{array}$ & 2.64 & 0.82 & Adoption Stage \\
\hline 4 & $\begin{array}{l}\text { Application of organic } \\
\text { fertilizer }\end{array}$ & $\begin{array}{l}10 \\
(2.54)\end{array}$ & $\begin{array}{l}18 \\
(4.57)\end{array}$ & $\begin{array}{l}23 \\
(5.83)\end{array}$ & $\begin{array}{l}43 \\
(10.91)\end{array}$ & $\begin{array}{l}147 \\
(37.30)\end{array}$ & $\begin{array}{l}153 \\
(38.83)\end{array}$ & 2.33 & 0.90 & Trial Stage \\
\hline 5 & Contour planting & $\begin{array}{l}7 \\
(1.78)\end{array}$ & $\begin{array}{l}9 \\
(2.28)\end{array}$ & $\begin{array}{l}34 \\
(8.69)\end{array}$ & $\begin{array}{l}82 \\
(20.81)\end{array}$ & $\begin{array}{l}133 \\
(33.76)\end{array}$ & $\begin{array}{l}129 \\
(32.74)\end{array}$ & 1.96 & 0.50 & Evaluation Stage \\
\hline 6 & Improved farrows & $\begin{array}{l}5 \\
(1.27)\end{array}$ & $\begin{array}{l}13 \\
(3.30)\end{array}$ & $\begin{array}{l}36 \\
(9.14)\end{array}$ & $\begin{array}{l}55 \\
(13.96)\end{array}$ & $\begin{array}{l}145 \\
(36.80)\end{array}$ & $\begin{array}{l}140 \\
(35.53)\end{array}$ & 2.13 & 0.69 & Trail Stage \\
\hline 7 & Terracing & $\begin{array}{l}3 \\
(0.76)\end{array}$ & $\begin{array}{l}7 \\
(1.78)\end{array}$ & $\begin{array}{l}22 \\
(5.58)\end{array}$ & $\begin{array}{l}35 \\
(8.88)\end{array}$ & $\begin{array}{l}160 \\
(40.61)\end{array}$ & $\begin{array}{l}167 \\
(42.39)\end{array}$ & 2.54 & 0.73 & Adoption Stage \\
\hline 8 & Intercropping & $\begin{array}{l}2 \\
(0.51)\end{array}$ & $\begin{array}{l}5 \\
(1.27)\end{array}$ & $\begin{array}{l}9 \\
(2.28)\end{array}$ & $\begin{array}{l}11 \\
(2.80)\end{array}$ & $\begin{array}{l}177 \\
(44.92)\end{array}$ & $\begin{array}{l}190 \\
(48.22)\end{array}$ & 2.90 & 0.86 & Adoption Stage \\
\hline 9 & Zero tillage & $\begin{array}{l}6 \\
(1.52)\end{array}$ & $\begin{array}{l}12 \\
(3.05)\end{array}$ & $\begin{array}{l}17 \\
(4.31)\end{array}$ & $\begin{array}{l}20 \\
(5.08)\end{array}$ & $\begin{array}{l}167 \\
(42.39)\end{array}$ & $\begin{array}{l}171 \\
(43.40)\end{array}$ & 2.60 & 0.71 & Adoption Stage \\
\hline 10 & Crop rotation & $\begin{array}{l}6 \\
(1.52\end{array}$ & $\begin{array}{l}14 \\
(3.55)\end{array}$ & $\begin{array}{l}13 \\
(3.30)\end{array}$ & $\begin{array}{l}23 \\
(5.83)\end{array}$ & $\begin{array}{l}150 \\
(38.07)\end{array}$ & $\begin{array}{l}188 \\
(47.72)\end{array}$ & 2.86 & 0.84 & Adoption Stage \\
\hline 11 & Afforestation & $\begin{array}{l}15 \\
(3.81)\end{array}$ & $\begin{array}{l}28 \\
(7.11)\end{array}$ & $\begin{array}{l}136 \\
(34.52)\end{array}$ & $\begin{array}{l}145 \\
(36.80)\end{array}$ & $\begin{array}{l}40 \\
(10.15)\end{array}$ & $\begin{array}{l}30 \\
(7.61)\end{array}$ & 0.46 & 0.23 & Awareness Stage \\
\hline 12 & Bush fallowing & $\begin{array}{l}6 \\
(1.52)\end{array}$ & $\begin{array}{l}16 \\
(4.06)\end{array}$ & $\begin{array}{l}21 \\
(5.33)\end{array}$ & $\begin{array}{l}26 \\
(6.60)\end{array}$ & $\begin{array}{l}156 \\
(39.60)\end{array}$ & $\begin{array}{l}169 \\
(42.90)\end{array}$ & 2.57 & 0.82 & Adoption Stage \\
\hline 13 & Salinity management & $\begin{array}{l}3 \\
(0.76)\end{array}$ & $\begin{array}{l}10 \\
(2.54)\end{array}$ & $\begin{array}{l}14 \\
(3.55)\end{array}$ & $\begin{array}{l}34 \\
(8.63)\end{array}$ & $\begin{array}{l}162 \\
(41.12)\end{array}$ & $\begin{array}{l}171 \\
(43.40)\end{array}$ & 2.60 & 0.71 & Adoption Stage \\
\hline 14 & $\begin{array}{l}\text { Application of inorganic } \\
\text { fertilizer }\end{array}$ & $\begin{array}{l}9 \\
(2.28)\end{array}$ & $\begin{array}{l}11 \\
(2.80)\end{array}$ & $\begin{array}{l}143 \\
(36.30)\end{array}$ & $\begin{array}{l}180 \\
(45.69)\end{array}$ & $\begin{array}{l}32 \\
(8.12)\end{array}$ & $\begin{array}{l}19 \\
(4.82)\end{array}$ & 0.29 & 0.21 & Awareness Stage \\
\hline
\end{tabular}


International Journal of Agriculture and Environmental Research

ISSN: 2455-6939

Volume: 07, Issue: 06 "November-December 2021"

\begin{tabular}{|c|c|c|c|c|c|c|c|c|c|c|}
\hline 15 & Contour bunds & $\begin{array}{l}2 \\
(0.51)\end{array}$ & $\begin{array}{l}9 \\
(2.28)\end{array}$ & $\begin{array}{l}11 \\
(2.80)\end{array}$ & $\begin{array}{l}19 \\
(4.82)\end{array}$ & $\begin{array}{l}180 \\
(45.69)\end{array}$ & $\begin{array}{l}173 \\
(43.91)\end{array}$ & 2.63 & 0.72 & Adoption Stage \\
\hline 16 & Creation of water channels & $\begin{array}{l}8 \\
(2.03)\end{array}$ & $\begin{array}{l}10 \\
(2.54)\end{array}$ & $\begin{array}{l}165 \\
(41.88)\end{array}$ & $\begin{array}{l}154 \\
(39.09)\end{array}$ & $\begin{array}{l}32 \\
(8.12)\end{array}$ & $\begin{array}{l}25 \\
(6.35)\end{array}$ & 0.38 & 0.29 & Awareness Stage \\
\hline 17 & Soak-away pits & $\begin{array}{l}3 \\
(0.76)\end{array}$ & $\begin{array}{l}56 \\
(14.21)\end{array}$ & $\begin{array}{l}139 \\
(35.28)\end{array}$ & $\begin{array}{l}155 \\
(39.34)\end{array}$ & $\begin{array}{l}17 \\
(4.31)\end{array}$ & $\begin{array}{l}24 \\
(6.09)\end{array}$ & 0.37 & 0.26 & Awareness Stage \\
\hline & Aggregate Mean & & & & & & & 2.51 & 0.66 & Adoption Stage \\
\hline
\end{tabular}

Key; Aware (A); Interest (I); Evaluation (E); Trail (T); Accept (Ap) and Satisfaction (S); Decision Rule;Less than 1.0 = Awareness stage; 1.00-1.49 = Interest Stage; 1.50-1.99 = Evaluation Stage; 2.00-2.49 = Trail stage; Stage; 2.50-2.99 = Adoption stage; 3.00-3.49 = Discontinued Stage; *Figures in parenthesis are percentage; AS: Adoption Stage and IS: Interest Stage; Field Survey Data, 2021 


\subsection{Constraints confronted with arable crop farmers in adopting soil conservation practices}

Output in Table 6 reveals the constraints confronted with arable crop farmers in adopting soil conservation practices in the area. It shows that about $96.54 \%$ and $93.83 \%$ of the farmers identified inadequate adoption fund and limited availability of farmland respectively as the constraints they face. Inadequate fund left most of the farmers unable to adopt some soil conservation measures and expand their production frontiers. For instance, farmers may want to adopt better but highly costly soil conservation measures; however, inadequate fund will pose a significant barrier. Limited availability of farmland left most of the farmers unable to adopt practices such as crop rotation among others coupled with high labour demand (92.84\%) of soil conservation measures. Also most soil conservation measures such as mixed cropping and intercropping as well as application of fertilizer (organic and inorganic) could be labour intensive and farmers who have low households size as well as lack fund area unable to provide labour for this operation. The result is in in tandem with the findings of Nwaiwu (2015) and Ali, Awuni, Danso-Abbeam (2018); Orgu, Chukwu, Onubuogu and Esiobu (2021) who found that inadequate fund and high labour intensive of agricultural innovation poses a negative effect on adoption.Ultimately, there is no doubt that these constraints are responsible for pose adoption of soil conversation technologies in the area Hence, confronting these constraints will be vital in promoting not just nutrient replenishment, but controlling soil erosion, increase crop yield, income and standard of living of farmers in the area and maybe beyond.

\section{Table 6: Constraints confronted with arable crop farmers in adopting soil conservation practices}

\begin{tabular}{llll}
\hline S/No & Item & Frequency & Percentage (\%) \\
\hline 1 & Inadequate adoption fund & 391 & 96.54 \\
2 & Limited availability of farmland & 380 & 93.83 \\
3 & High labour demand & 376 & 92.84 \\
4 & Unavailability of raw material & 370 & 91.36 \\
5 & Increase in pest infestation & 361 & 89.14 \\
6 & High cost of materials & 352 & 86.91 \\
7 & Environmental pollution & 347 & 85.68 \\
8 & Encourages weed growth & 330 & 81.48 \\
9 & Ignorance of the soil conservation practice & 328 & 23.95 \\
\hline
\end{tabular}

*Multiple responses were recorded; Source: Field Survey Data, 2021 
International Journal of Agriculture and Environmental Research

ISSN: 2455-6939

Volume: 07, Issue: 06 "November-December 2021"

\section{CONCLUSION AND RECOMMENDATION}

Conclusively, findings of this study suggest that arable crop farmers adopted some of the soil conservation practices disseminated to them such as Mixed cropping ( $\overline{\mathrm{x}}=2.63 ; \mathrm{SD}=0.81$ ), Planting of cover crops $(\overline{\mathrm{x}}=2.68 ; \mathrm{SD}=0.91)$, Mulching $(\overline{\mathrm{x}}=2.63 ; \mathrm{SD}=0.87)$ amongst others and afforestation is yet to get to adoption stage. Also, arable crop farmers in the study area were aware of soil conservation measures. Cost, availability, simplicity and compatibility among others were the significant factors that influence willingness to pay and adopt soil conservation measures. Complexity of the soil conservation measures affect adoption negatively. Soil conservation measures are profitable given the outcome of the NPV. There is no doubt that if more investments are made on all the soil conservation measures yielding positive NPV, it will lead to a significant increase in income, yield, food security and standard of living on the farmers in the area and perhaps beyond. Strengthened extension services delivery that would adequately support farmers and extended education programs geared towards broadening farmers' knowledge on benefits inherent in soil conservation should be promoted. The challenges in the adoption of soil conservation strategies were the inadequate adoption fund, limited availability of farmland, high labour demand amongst others. The arable crop farmers believed that adoption of soil conservation strategies requires more expenditures and incentives should be provided to encourage them. Also, formation of farmers' group should be encouraged among farmers as it enhances information sharing about soil conservation measures, hence favouring the ease of adoption of soil conservation in the area. Also arable crop farmers should be encouraged to practice afforestation, as it will not only conserve the soil but also our climate.

\section{REFERENCES}

[1] Abu, G.A., Taangahar, T.E., \& Ekpebu, D.I. (2011). Proximate determinants of farmers WTP (willingness to pay) for soil management information service in Benue State, Nigeria, African Journal of Agricultural Research, 6(17), 4057-4064

[2] Ademola, A.O., \& Olujide, M.G. (2014). Soil Conservation Practices of Arable Crop Farmers in Atisbo Local Government Area of Oyo State, Nigeria, Advances in Research 2(12): 879-888

[3] Aja, O.O., Ani, A.O., Matthews-Njoku, E.C. \& Ifeanyi-Obi, C.C. (2015).Behavioural Adaptations Of Small-Holder Farmers In Soil Erosion Endemic Areas Of Imo State, Nigeria, International Journal of Advanced Biology, 5(3), 236-242

[4] Akinnagbe, O. M, Onah C.P., Olaolu, M. O. andAjayi, A.R (2014). Farmers' Perceived Impact of Climate Change on Agricultural Activities in Otukpo Local Government Area of Benue state, Nigeria. International Journal of Tropical Agricultural Research and extension (TARE journal). 15(5), 257-274 
International Journal of Agriculture and Environmental Research

ISSN: 2455-6939

Volume: 07, Issue: 06 "November-December 2021"

[5] Ali, E. B. Awuni, J.A \& Danso-Abbeam, G (2018). Determinants of fertilizer adoption among smallholder's cocoa farmers in the Western Region of Ghana, Cogent Food and Agricuture, 4(1), 153-162

[6] Anyiam, K.H., Nwaiwu, I.U.O., Obi-Nwandikom, C.O., \& Ibeagwa, O.B (2021). Determinants of Farmland Value in Imo State, Nigeria, International Journal of Life Sciences, 10(1), 21-27

[7] Aromolaran, A. B. (1998). Economic Analysis of Soil Conservation Practices in South West Nigeria "Issues in African Rural Development. Monograph Series African Rural Social Science Research Network, WinRock international.

[8] Daudu, A.K. (2016). Gender Involvement in Soil Fertility Management Practices among Smallholder Arable Crop Farmers in Kwara State, Nigeria. An unpublished Ph.D. Agric. Extension Thesis in the Department of Agricultural Extension and Rural Development, University of Ilorin, Ilorin, Nigeria, 46-48.

[9] Elenwa C.O., \& Emodi A.I. (2019). Soil conservation practices among rural farmers in arable crop production in Omuma Local Government Area of Rivers State, Nigeria. Agro-Science, 18 (3), $42-47$.

[10] Ellis, F. (2000). Farm Households and Agrarian Development. Cambridge University Press,Cambridge

[11] Enete A.A., \& Amusa T.A. (2010). Challenges of Agricultural Adaptation to Climate Change in Nigeria: a Synthesis from the Literature. A paper presented at an international conference on "Enhancing agricultural adaptation to climate change" which was held on the 27th of July 2010 at Enugu, Nigeria

[12] Food and Agriculture Organization (FAO) (2007). Conservation Agriculture. Department of Agriculture and Consumer Protection, Food and Agriculture Organization (FAO), Rome

[13] Food and Agriculture Organization (FAO) (2020). The role of women in agriculture, Retrieved on 10 April https://www.fao.org/3/am307e/am307e00.pdf

[14] Ibewiro, B., N., Sanginga, B., Vanlauwe, \& Merckx, R. (2000). Nitrogen contributions from decomposing cover crop residues to maize in a tropical derived savanna. Nutrient Cycling in Agroecosystems, 5(7), 131-140.

[15] Igbokwe, E.M. (1996). A Soil and Water Conservation System Under Threat. A Visit to Maku,Nigeria. In: Sustaining the Soil-Indigenous Soil and Water Conservation in Africa, Reij,C., I. Scoones and C. Toulmin (Eds.). Earthscan Publication, London, UK.,219-343.

[16] Iheke O.R., \& Onyenorah, C. O. (2012). Awareness, Preferences and Adoption of Soil Conservation Practices among Farmers in Ohafia Agricultural Zone of Abia State, Nigeria. Journal of Sustainable Agriculture and the Environment, 13(1): 1-8 
International Journal of Agriculture and Environmental Research

ISSN: 2455-6939

Volume: 07, Issue: 06 "November-December 2021"

[17] Ikuerowo, J.O. \& Tehinloju, O. A. (2020).Factors Influencing Arable Crop Farmers' Willingness to Adopt Bio-Organic Technology in Ondo State, Nigeria, Journal of Agricultural Extension, 25 (1),21-30

[18] Lizarazo, C.I., Tuulos, A., Jokela, V., \& Mäkelä, P.S.A (2020). Sustainable Mixed Cropping Systems for the Boreal-Nemoral Region. Front. Sustain. Food Syst. 4(3), 103115

[19] Ministry of Land Survey and Urban Planning (2015). Area of Imo State by LGA, Government Printer, Owerri. Imo State, Nigeria.

[20] Mohamed, A.A., \& Nageye, A.I. (2021). Measuring the effect of land degradation and environmental changes on agricultural production in Somalia with two structural breaks, Management of Environmental Quality, 32(2), 160-174

[21] National Boundary Commission (NBC) of Nigeria (2020). Boundaries across South east, Nigeria, Retrieved on 10 April 2021 from https://nnn.ng/tag/national-boundarycommission-nbc/

[22] National Bureau of Statistics (NBS) (2007). National Bureau of Statistics Official Gazette (FGP 71/52007/2,500(OL24): Legal Notice on Publication of the Details of the Breakdown of the National and State Provisional Totals, 2006 Census. Retrieved 28th March, 2021 from www.nigerianstat.gov.ng

[23] National Root Crops Research Institute, Umudike Meteorological Station, (NRCRIMS) (2020). Rainfall pattern across South east Nigeria, Retrieved 28th March, 2021 from NRCRIMS archive

[24] Ndulue, D.C., Ayadiuno, R.U., Mozie, A.T., \& Ndichie, C.C. (2021). A Comparative Analysis of Soil Erosion Models for Tropical Humid of Southeastern Nigeria and Comparable Environments, Psychology And Education, 58(1), 5821-5835

[25] Nigeria Population Commission (NPC) (2006). Nigeria Population Commission, Nigeria Federal Government Initiative of individual head count by gender. Spread, State by State, In :MOFINEWS; 6(3): Nigeria; Retrieved 28th March, 2021 from https://www.nationalpopulation.gov.ng/

[26] Nigerian Meteorological Agency (NiMET) (2020). Drought, Rainfall and Flood Monitoring in South-East Bulletin 2020. Retrieved 28th March, 2021, from www.nimet.gov.ng

[27] Nwaiwu, J.C. (2015). Socio-economic Factors influencing arable crop farmers' adoption of environmental conservation measures in South Eastern Nigeria: International Journal of Research in Agriculture and Forestry, 2 (3), 20-25

[28] Ojo, M.A., Egbelehulu, D., Olaleye, R.S., Ojo, A.O.,Tsado, J., \& Ajayi, O.J. (2013). Analysis Of Soil Conservation Practices And Adoption in Federal Capital Territory of 
International Journal of Agriculture and Environmental Research

ISSN: 2455-6939

Volume: 07, Issue: 06 "November-December 2021"

Nigeria, International Journal of Agricultural Economics and Extension Services, 3(1 ), $1-8$,

[29] Oladipo, F.O., Bolarin, O., Daudu, A.K., Kayode, A.O., \& Awoyele, P.O (2017). Utilization Of Soil Conservation Practices Among Root And Tuber Farmers In Oyun Local Government Area Of Kwara State, Nigeria, Agrosearch, 17(2) 99-109

[30] Orgu, K.C., Chukwu, A.O., Onubuogu, G.C., \&Esiobu, N.S (2021).Do Rural Livestock Farmers' have Knowledge of Organic Farming Practices? Lesson from Southeast, Nigeria, Book, UK, DOI: 10.5772/intechopen.99961, 4(3) 1-18

[31] Sahya, M., Oliver, J. H., Bornwell, M., Joseph M., \& Enock, S. (2021). Enhancing the role of rural agricultural extension programs in poverty alleviation: A review, Cogent Food \& Agriculture, 7(1),5-11

[32] Salako, F. K., \& Tian, G. (2003). Soil water depletion under various leguminous cover crops in the derived savanna of West Africa, International Journal of Research in Agriculture and Forestry, 100(3), 173-180.

[33] Solomon, E.M., Tadesse, Z.L., Markew, M.N., and Wudineh, A.D. (2021). Perception and determinants of agricultural technology adoption in North Shoa Zone, Amhara Regional State, Ethiopia, Cogent Economics \& Finance, 9(1),2-12 Rogers, E.M. (1995). Diffusion of Innovations., New York: Free Press, 4

[34] Tian, G., Kolawole, G., Salako, F., \& Kang, B. (1999). An improved cover crop-fallow system for sustainable management of low activity clay soils of the tropics. Soil Science, 164(9): 671-682.

[35] Wordofa, M.G., Okoyo, E.N. \& Erkalo, E. (2020). Factors influencing adoption of improved structural soil and water conservation measures in Eastern Ethiopia. Environ Syst Res, 9(13), 4-12 